\title{
Association and distribution of the ciliate Orchitophrya stellarum with asteriid sea stars on the west coast of North America
}

\author{
William B. Stickle ${ }^{1, *}$, Eugene N. Kozloff ${ }^{2}$ \\ ${ }^{1}$ Department of Biological Sciences, Louisiana State University, Baton Rouge, Louisiana 70803-1715, USA \\ ${ }^{2}$ Friday Harbor Laboratories, University of Washington, Friday Harbor, Washington 98250, USA
}

\begin{abstract}
The association of the scuticociliate Orchitophrya stellarum with 3 species of asteriid sea stars from the west coast of North America was studied by flushing the gonopore region with seawater and spawning the sea stars, along a latitudinal gradient of $2549 \mathrm{~km}$ between Pigeon Point, California, and Kodiak, Alaska. Asterias forbesii and A. rubens from the Isles of Shoals, New Hampshire (east coast), were also sampled. The ciliate was found on the aboral surface of both sexes of reproductively ripe Evasterias troschelii, Leptasterias spp., and Pisaster ochraceus with a maximum intensity of association occurring at Cape Arago, Oregon, and Clallum Bay and Manchester Dock, Washington. A survey of gonad smears and hematoxylin and eosin-stained sections indicated that the ciliate was only present in males. Spring-spawning E. troschelii and $P$. ochraceus are more negatively impacted by the ciliate than are winter-spawning Leptasterias spp. as judged by a skewed sex ratio and sex size differences, which may be associated with seasonal differences in water temperature affecting the growth rate of $O$. stellarum. The external morphology of $O$. stellarum appears to be similar throughout the geographical range surveyed.
\end{abstract}

KEY WORDS: Orchitophrya stellarum • Asteriid sea stars · Ciliate · Parasite · Geographical distribution · Commensal

Resale or republication not permitted without written consent of the publisher

\section{INTRODUCTION}

Orchitophrya stellarum phagocytizes spermatozoa in 7 species of asteriid sea stars from the North Atlantic and Pacific oceans. Earlier reports of O. stellarum as a parasite of sea stars in the European north Atlantic were followed by accounts of its presence in sea stars on the east coast of North America, then in the Pacific Ocean (Stickle et al. 2001a,b, 2007a). Greater virulence of the parasite among sea stars in the Pacific Ocean has been attributed to its recent introduction from the Atlantic Ocean (Leighton et al. 1991, Byrne et al. 1997, 1998).

Orchitophrya stellarum belongs to the scuticociliate family Paranophryidae, which is closely related to other groups that are endoparasitic, histophagic, ectoor endocommensal associates of various species of invertebrates (Bouland et al. 1987, de Puytorac 1994, Dragesco et al. 1995). This ciliate can be cultured in seawater. O. stellarum feeds on bacteria in infusions of yeast extract and animal tissue, which strongly suggests that it is probably of widespread occurrence in situations where organic substances are undergoing decomposition. Observations on $O$. stellarum cultured in seawater containing bacteria show that the size and morphology of the ciliate in the free-living phase are very different from those parasitizing testes (Stickle et al. 2007a). Furthermore, ciliates have been experimentally transmitted from seawater to uninfected male Leptasterias spp. (Stickle et al. 2007b), a species complex throughout its range on the west coast of North America (Flowers \& Foltz 2001).

Earlier studies of male sea stars parasitized by the ciliate were based on the appearance of Orchitophrya stellarum in the testes or a skewed population structure of the sea stars at specific locales (see Stickle et al. $2001 a, b)$. The impact of the parasite on sea stars has been based on (1) significantly fewer and smaller 
males than females, and (2) significantly smaller testis indices in parasitized than in non-parasitized males. The ciliate parasitizes males, but not females, based on its presence in sections and smears of testes but not in ovaries.

Orchitophrya stellarum has been identified in southern British Columbia (BC, Canada), the San Juan Islands and Puget Sound, Washington (WA, USA), where it parasitizes Pisaster ochraceus, Evasterias troschelii, and Leptasterias spp. (Leighton et al. 1991, Stickle et al. 2001a,b), and in Japan, where it parasitizes Asterias amurensis (Byrne et al. 1997, 1998). Nucleotide sequence data of the internal transcribed spacers and the 5.8S gene in the ribosomal RNA gene cluster of $O$. stellarum from 4 species of asteriid hosts from the Atlantic and Pacific Oceans were identical (Goggin \& Murphy 2000). The global dispersal of many free-living microbial eukaryote species (Finlay 2002) supports the observation of the lack of genetic differentiation in nucleotide sequences in O. stellarum due to their global dispersal.

The objectives of the present study were to (1) compare methods used to determine the association of Orchitophrya stellarum with asteriid sea stars; (2) determine the association of $O$. stellarum with the common species of asteriid sea stars on the west coast of North America and with 2 species from the Isles of Shoals, New Hampshire ( $\mathrm{NH}_{\text {; }}$ east coast USA); (3) determine the impact of the ciliate on local populations of asteriid sea stars from the west coast of North America; and (4) observe the surface phenotypic characteristics of $O$. stellarum from throughout its range on the west coast of North America and the Isles of Shoals.

\section{MATERIALS AND METHODS}

Methods of assessment of the ciliate in association with asteriid sea stars. One collection of each species of sea star from the west coast of North America was subject to all 4 ciliate assessment techniques in order to determine their ability to identify the presence of the parasite. Leptasterias spp. $(n=61)$ were collected intertidally from Lonesome Cove on San Juan Island, WA, on 27 November 2000. Evasterias troschelii $(\mathrm{n}=49)$ and Pisaster ochracheus $(\mathrm{n}=52)$ were collected with SCUBA gear from the dock pilings at the NOAA Fisheries Services Manchester Research Station, WA, on 3 June 2001.

Two methods were used to determine the association of Orchitophrya stellarum with these species of sea stars. Initially, the aboral surface of the central disc of each sea star was flushed with filtered seawater (0.2 $\mu \mathrm{m}$, Millipore), and the sea star was inverted so that the seawater drained into a plastic weighing dish. Fluid containing the seawater was examined for the presence of $O$. stellarum. Each sea star was then injected with $1 \mathrm{ml}$ of $100 \mu \mathrm{M} 1$ methyl-adenine per $100 \mathrm{~g}$ wet weight into the central disc near the base of the rays and placed with its aboral side down over a plastic weighing dish for $20 \mathrm{~min}$. Fluid containing gametes was examined for the presence of $O$. stellarum.

Two methods were also used to determine the infection of the gonads of these species of sea stars with Orchitophrya stellarum. After dissection of sea stars, gonadal tissue was smeared on a microscope slide, and several drops of filtered sea water $(0.2 \mu \mathrm{m}$, Millipore) were added to the slide. Material on the slide was observed for the presence of living O. stellarum. Gonadal tissue was also preserved in $10 \%$ buffered formalin adjusted in osmolality to equal 30 psu for at least $24 \mathrm{~h}$, rinsed twice with $0.1 \mathrm{M}$ sodium cacodylate in $3 \%$ sucrose, and stored in the same buffer at $5^{\circ} \mathrm{C}$ until prepared for histology. The tissue was dehydrated in an alcohol series, embedded in paraffin, sectioned, and stained with hematoxylin and eosin (H\&E). Sections were visually examined for the presence of ciliates.

Data from the 4 methods used to determine the association of Orchitophrya stellarum with the 3 species of sea stars were compared with the mixed ANOVA procedure of the Statistical Analysis System (SAS Institute 2003). Significant differences were considered to exist if $\mathrm{p}<0.05$.

Distribution of Orchitophrya stellarum on asteriid sea stars. Three species of asteriid sea stars were surveyed at a number of locales between Point Pinos, California (CA), and Kodiak Island, Alaska (AK), while their gonads were ripe. Leptasterias spp. were collected intertidally at Sunshine Cove and Little Port Walter, AK, Lonesome Cove, WA, and Pigeon Point, CA. Evasterias troschelii were collected with SCUBA from the dock at Manchester, WA, and at Little Port Walter, AK, while intertidal collections were made at Sunshine Cove and Kodiak, AK. Pisaster ochraceus were collected intertidally from Pigeon Point, CA, Cape Arago, Oregon (OR), Clallam Bay, WA, Bamfield and Port Hardy, BC, and Sitka, AK, while collections were made with SCUBA at Manchester Dock, WA, and Little Port Walter, AK (see Fig. 2A). A collection of Asterias forbesii and A. rubens was also made with SCUBA at the Isles of Shoals, $\mathrm{NH}$, and flown to Louisiana State University (LSU) where sea stars were analyzed.

Sea stars were weighed wet and the aboral central disc was flushed with 30 psu filtered sea water $(0.2 \mu \mathrm{m}$, Millipore). Each sea star was inverted on a plastic weighing dish, and several drops of the fluid that drained into the dish were observed under a compound microscope at $100 \times$ magnification for the presence of Orchitophyra stellarum. A needle biopsy was 
taken from a gonad of each sea star in order to ascertain its sex by the presence of either ova or spermatozoa.

The average wet weight of male and female sea stars was compared with paired $t$-tests, with significant differences indicated at the $\mathrm{p}<0.05$ level. The number of male and female sea stars collected at each locale was statistically compared with chi-squared analysis of the expected 1:1 ratio.

For scanning electron microscopy (SEM), ciliates were fixed in a glutaraldehyde-osmium bath $(3 \%$ glutaraldehyde-1\% osmium tetroxide in cacodylate buffer) for $1 \mathrm{~h}$. Fixed cells were collected on a $0.2 \mu \mathrm{m}$ polycarbonate filter that was critical-point dried with a Denton DCP-1 apparatus and coated with gold-palladium (80-20) using an Edwards S150 sputter coater. The preparations were imaged with a Cambridge 260 Stereoscan SEM.

\section{RESULTS}

The 4 methods used to determine the association of Orchitophrya stellarum with the 3 species of sea stars sampled, Evasterias troschelii, Leptasterias spp., and Pisaster ochracheus, yielded different intensities of association with the 2 sexes of sea stars (Table 1). The mixed ANOVA procedure to determine the variance components of the association indicated that there were significant differences among species, sex, species by sex, method of determination, species by method, and sex by method. Only the variance due to species by sex by method interaction term was not significant, indicating that there was no significant difference in the manner by which the ciliate was associated with each sex of E. troschelii, Leptasterias spp., and P. ochracheus.

The fluid containing irrigation seawater or spawn that flushed the area around the gonopores of sea stars contained more Orchitophrya stellarum than was observed in smears or histological sections of the

Table 1. Mixed procedure model ANOVA results of the association of the ciliate Orchitophrya stellarum with 3 species of asteriid sea stars, Evasterias troschelii, Leptasterias spp., and Pisaster ochracheus

\begin{tabular}{|lcrr|}
\hline Effect & df & \multicolumn{1}{c|}{$F$} & \multicolumn{1}{c|}{$\mathrm{p}>F$} \\
\hline Species & 2,155 & 9.56 & 0.0001 \\
Gender & 1,155 & 46.67 & $<0.0001$ \\
Species $\times$ Gender & 2,155 & 15.05 & $<0.0001$ \\
Method & 3,465 & 44.64 & $<0.0001$ \\
Species $\times$ Method & 6,465 & 5.37 & $<0.0001$ \\
Gender $\times$ Method & 3,465 & 3.46 & 0.0163 \\
Species $\times$ Gender $\times$ Method & 6,465 & 1.36 & 0.2303 \\
\hline
\end{tabular}

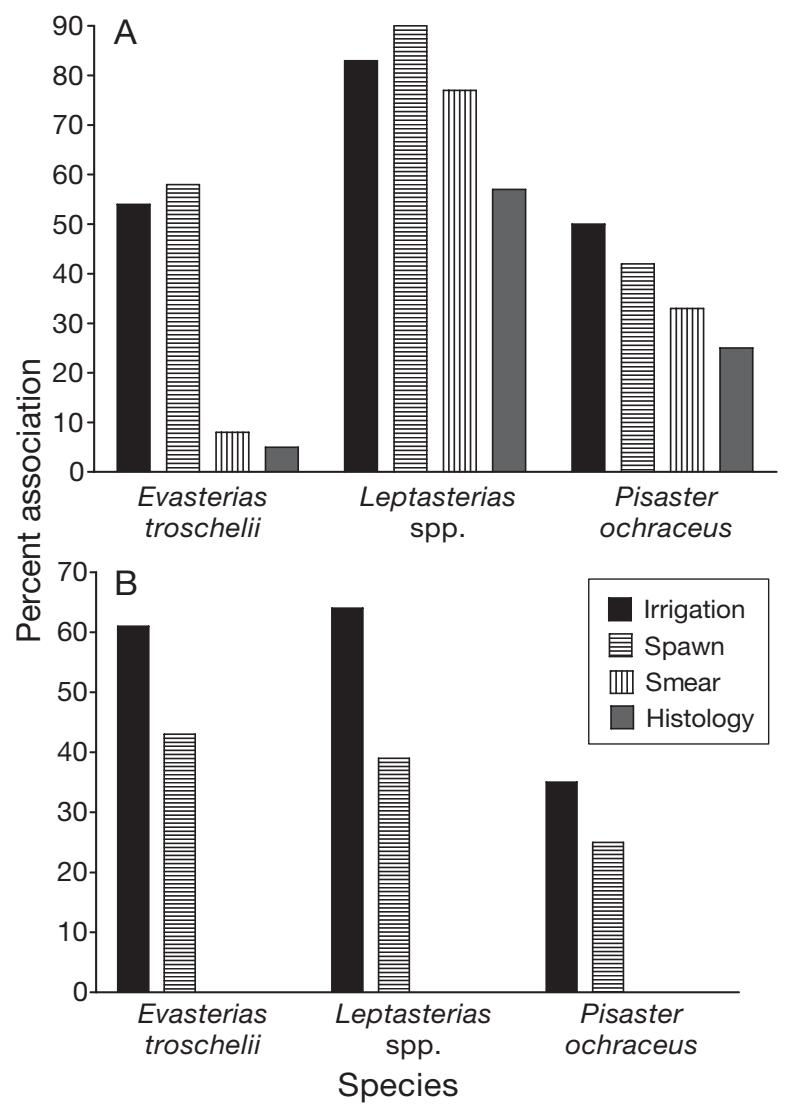

Fig. 1. Comparison among 4 methods of determining the relationship between Orchitophyra stellarum and 1 collection each of 3 species of sea stars. Percent of (A) male and (B) female sea stars associated with or parasitized by $O$. stellarum are given for Evasterias troschelii and Pisaster ochraceus collected from Manchester Dock, WA, and for Leptasterias spp. collected from Lonesome Cove, WA. Only males of the 3 species of sea stars were infected with $O$. stellarum as determined by gonad smears or hematoxylin and eosin (H\&E)stained sections of gonadal tissue

gonads (Fig. 1). O. stellarum was associated with the external surface of both sexes of all 3 species of sea stars from the west coast of North America. However, only males had O. stellarum in their gonads, i.e. evidence of parasitism, as determined by both gonad smears and H\&E-stained sections of gonad tissue.

Orchitophrya stellarum was associated with asteriid sea stars at 9 locations between Pigeon Point, CA, and Sitka, AK (Fig. 2A). O. stellarum was most prevalent on sea stars at Cape Arago, OR, Manchester Dock and Clallam Bay, WA, and Little Port Walter, AK (Leptasterias spp. only; Fig. 2B-D). Both sexes of Pisaster ochraceus were minimally associated with O. stellarum at Port Hardy, BC, and Little Port Walter and Sitka, AK.

Spring-spawning and broadcasting male Evasterias troschelii and Pisaster ochraceus are severely impacted at several locations on the west coast of North America as judged by significantly fewer males than 

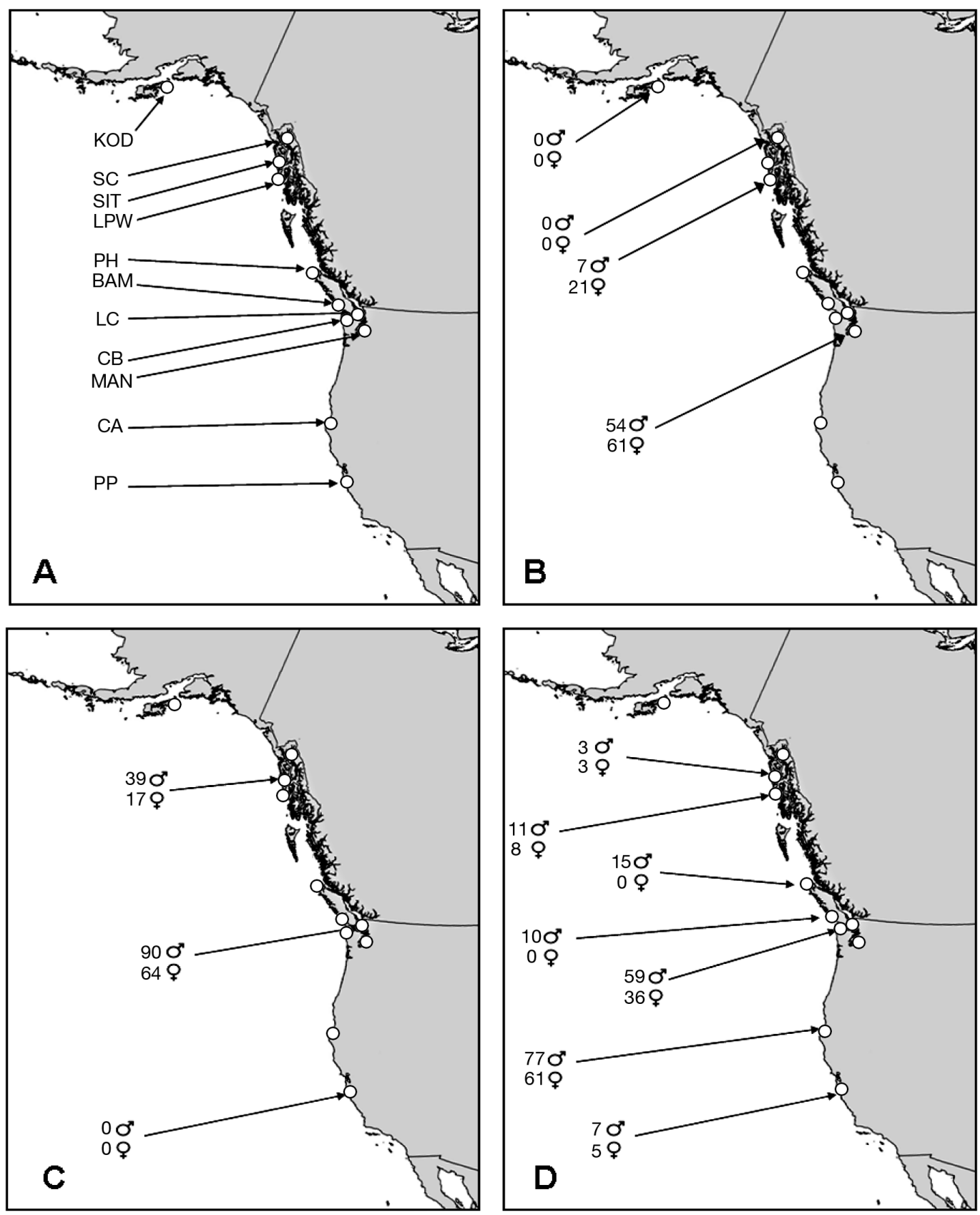

Fig. 2. Orchitophyre stellarum associated with 3 asteriid sea stars. (A) Sampling locales on the west coast of North America. PP: Pigeon Point, CA; CA: Cape Arago, OR; MAN: Manchester Dock, WA; CB: Clallum Bay, WA; LC: Lonesome Cove on San Juan Island, WA; BAM: Bamfield, BC; PH: Port Hardy, BC; LPW: Little Port Walter, AK; SIT: Sitka, AK; SC: Sunshine Cove on Lynn Canal, AK, KOD: Fort Abercrombie near Kodiak, AK. Percent of male and female: (B) Evasterias troschelii associated with the ciliate at collecting locales; (C) Leptasterias spp. associated with the ciliate; (D) Pisaster ochraceus associated with the ciliate

females, suggesting prior male mortality. We found significantly fewer $E$. troschelii males than females ( $p<$ 0.05 ) even though there was no association of either sex with the ciliate at the time of sampling at Kodiak, AK. P. ochraceus collected at Bamfield, BC, exhibited evidence of prior male mortality because there were significantly fewer males than females $(p<0.05)$, but males were only minimally associated with Orchitophrya stellarum $(10 \%)$ at the time of sampling. There were significantly more male $P$. ochraceus than the expected number of females at Little Port Walter, AK $(\mathrm{p}<0.05)$, and more male than female Asterias rubens 
at the Isles of Shoals, NH ( $p<0.05)$, but this observation could not be due to female mortality due to parasitism by $O$. stellarum. We do not know of a causative reason for an increased male:female ratio in sea stars. In contrast, Leptasterias spp. were never observed to be severely impacted by $O$. stellarum as determined by relative numbers of males and females or the relative size of the 2 sexes. Male and female wet weights were not significantly different in any of the 5 species of asteriid sea stars sampled from 12 locales in this study.

Both sexes of Asterias forbesi and A. rubens from the Isles of Shoals, NH, were associated with Orchitophrya stellarum. The association of $O$. stellarum was $16 \%$ with male $A$. forbesi $(\mathrm{N}=25)$ and $14 \%$ with females $(\mathrm{N}=37)$. The association of the ciliate was $43 \%$ with male $A$. rubens $(\mathrm{N}=35)$ and $8 \%$ with females $(\mathrm{N}=13)$. There were significantly more males than females in the sample of $A$. rubens ( $\mathrm{p}<0.05)$.

Orchitophrya stellarum collected from Pigeon Point, CA, Clallam Bay, WA, Sitka, AK, and the Isles of Shoals, NH, are morphologically similar as judged from observations of SEM micrographs of the ciliate from those locations (Fig. 3). Ciliary tracts and a terminal cilium are characteristic phenotypic features of the
SEMs of all 4 specimens from geographically separated locales.

\section{DISCUSSION}

Orchitophrya stellarum is a commensal on the external surface of both sexes of asteriid sea stars on the west coast of North America from Pigeon Point, CA, to Sitka, AK, a latitudinal range of $2549 \mathrm{~km}$, but only parasitizes the testes of males. The fact that the ciliate is found on the external surface of female sea stars is indicative that it can obtain adequate nutrition to maintain reasonable population numbers as a commensal. Stickle et al. $(2007 \mathrm{a}, \mathrm{b})$ cultured this ciliate in seawater with baker's yeast as a nutritional source for bacteria and animal tissue including sloughed off epidermal tissue.

Different methods should be used to determine the association of Orchitophrya stellarum with species of asteriid sea stars and the degree of parasitism of male sea stars. The most efficient way to determine if $O$. stellarum is present at a specific locale is to irrigate the gonopore region of reproductively ripe asteriid sea


Fig. 3. Orchitophyre stellarum. Scanning electron microscopy (SEM) micrographs of ciliates flushed from the aboral surface of the central disc of (A-C) Pisaster ochraceus from (A) Sitka, AK, (B) Clallam Bay, WA, (C) Pigeon Point, CA, or from (D) Asterias forbesi from the Isles of Shoals, $\mathrm{NH}$, and maintained in a culture of bacterized yeast in seawater for several days before preparation for SEM analysis 
stars with Millipore-filtered seawater and to survey the collected water for the presence of the ciliate under a compound microscope at 100× magnification as we did with the 3 species surveyed (Fig. 1). The probability of finding the ciliate if it is present in the local population of sea stars is 1.1 to 6.75 times greater than it is through the use of gonad smears of males. As much as 35 to $64 \%$ percent of females from those locales were associated with the ciliate. Assessment of the effects of parasitism on the asteriid sea stars by the ciliate should use wet weight determination of both sexes coupled with gonad smears of several testis lobules from males to confirm the presence of the ciliate.

The most intense association between Orchitophrya stellarum and asteriid sea stars on the west coast of North America was at Cape Arago, OR, and at Clallam Bay on the Straits of Juan de Fuca and Manchester Dock in Puget Sound, WA. Seasonal water temperature ranges may not be adequate to maintain ciliate numbers at Sitka, AK, where only $3 \%$ of Pisaster ochraceus males and females were associated with the ciliate or at Sunshine Cove on Lynn Canal and Kodiak Island, AK, where no Evasterias troschelii or Leptasterias spp. were associated with the ciliate. O. stellarum population growth is minimal at water temperatures of $3^{\circ} \mathrm{C}$ and is most rapid at $24^{\circ} \mathrm{C}$ and 30 psu in culture with a source of bacteria (Stickle et al. 2007b). O. stellarum has a greater negative impact on the springspawning and broadcast-fertilizing E. troschelii and $P$. ochraceus than it does on winter-spawning and brooding Leptasterias spp., perhaps because of a higher ambient water temperature in the late spring. We found that 1 of 7 sampled locales of E. troschelii, and 2 of 8 sampled locales of $P$. ochraceus had significantly fewer males than females. Leighton et al. (1991) first observed that male:female sex ratios were lower and significantly different than 1:1 in 1987, 1988, and 1989 in collections of $P$. ochraceus from Indian Arm and Bowen Island in southern British Columbia. Testis indices were also lower than in previous years, but these observations of unparasitized and parasitized testes were not compared on the same sampling date and location (Leighton et al. 1991). Stickle et al. (2001b) found that the male:female sex ratio and size of 4 of the 6 collections of male and female E. troschelii and $P$. ochraceus from Puget Sound, WA, differed from statistical expectations of similarity. In no case, however, was there a statistical difference in the testis indices of non-parasitized and parasitized male sea stars in these spring-spawning species.

In contrast, there was no significant difference in the M:F ratio or wet weight of Leptasterias spp. from 5 locales in this study, in the collection presented by Stickle et al. (2001b), or in 5 collections from San Juan Island, WA (Stickle et al. 2001a). Gonads are at their maximum degree of ripeness during the late fall and early winter when seasonal seawater temperature is approaching its minimum $\left(6^{\circ} \mathrm{C}\right)$. However, testis indices of parasitized Leptasterias spp. were significantly smaller than in non-parasitized males from the same collection in 2 of the 4 collections on San Juan Island, WA (Stickle et al. 2001a), indicating sublethal stress to the sea stars at that time.

Six locales off eastern Japan were found to have male Asterias amurensis that were parasitized by the presence of Orchitophrya stellarum in testes (Byrne et al. 1998). This is a latitudinal distance of only $538 \mathrm{~km}$. Several of these locales had fewer males than expected, indicating prior male mortality. O. stellarum were not found in the testes of $A$. amurensis south and west of Ise Bay in central Japan.

Genetic analysis indicates that Orchitophrya stellarum is very similar throughout its range in the northern hemisphere (Goggin \& Murphy 2000). Our SEM micrographs of $O$. stellarum ciliary tracts and the presence of caudal cilia indicate the similarity of $O$. stellarum associated with the gonopore region in the present study with this ciliate studied in detail during the parasite to free-living phase transition and from the parasitic phase of Leptasterias spp. (Stickle et al. 2001a). Ciliates in seawater culture are smaller and have a different morphology than those found in the testes tubules of males. During adaptation of $O$. stellarum to culture conditions, the ciliates become smaller, the number of kineties is reduced, and the buccal cavity is shifted farther away from the anterior end. These changes are reversed if the ciliates are fed asteriid sperm (Stickle et al. 2007a). Attempts to obtain silver-stained cilia tract impressions of $O$. stellarum obtained by a seawater flush of the gonopore region of sea stars collected from all locations were unsuccessful; these data would have provided definitive evidence of the ciliate's identity (Stickle et al. 2007a).

Orchitophrya stellarum is associated with asteriid sea stars of the eastern North Pacific at latitudes where the seasonal change in water temperature falls within the zone of capacity adaptation of the ciliate, i.e. 3 to $27^{\circ} \mathrm{C}$ (Stickle et al. 2007b). Seasonal changes in surface seawater temperature are relatively constrained, ranging from 12.1 to $15.4^{\circ} \mathrm{C}$ (1983 to 1993) at Monterrey, CA (Barry et al. 1995), from 6 to $13^{\circ} \mathrm{C}$ in the San Juan Islands, WA (Stickle 1970), and from 1 to $15^{\circ} \mathrm{C}$ at Sunshine (Ravioli) Cove along the Lynn Canal north of Juneau, AK (Stickle 1970, Stickle \& DeNoux 1976). Winter minimal seawater temperatures fall below the low temperature tolerance limit $\left(3^{\circ} \mathrm{C}\right.$; Stickle et al. $\left.2007 \mathrm{~b}\right)$ of $O$. stellarum at Sunshine Cove and Kodiak, AK, which could limit the ciliate's geographical distribution. In addition, aerial emersion 
of intertidal asteriid sea stars would not negatively impact the survival of the ciliate along the continental United States because winter spring tides occur during the day and summer spring tides occur at night (Helmuth et al. 2006). Only the Boiler, OR, exposed site exhibited an air temperature below freezing 1 mo out of the $4 \mathrm{yr}$ study (Helmuth et al. 2006). Intertidal zones north of the Straits of Juan de Fuca are exposed to freezing conditions in the winter and hot temperatures in the summer because spring tide lows occur during the night during the winter and during the day during the summer (Helmuth et al. 2006). Both of these temperature extremes would likely limit the geographical distribution of O. stellarum (Stickle et al. 2007b). Spring spawning sea stars are more severely impacted by parasitism by $O$. stellarum than winter spawning Leptasterias spp. probably because of warmer seawater temperatures when the ciliate is reproducing in the testes. Global warming may shift the geographical distribution of O. stellarum northward in the North Pacific Ocean.

Morphological similarity of Orchitophrya stellarum from throughout the geographical range of the asteriid sea stars sampled in the eastern North Pacific and the Isles of Shoals, NH, appear to substantiate the results of identical nucleotide sequence from the internal transcribed spacers and the 5.8S gene from the ribosomal RNA gene cluster of $O$. stellarum from 4 species of asteriid hosts from the Atlantic and Pacific Oceans (Goggin \& Murphy 2000). Additional silver staining of ciliary tracts or genetic analyses will be required to provide stronger evidence of the similarity of the ciliates. These data appear to support the observation of the global dispersal of many free-living microbial eukaryote species (Finlay 2002).

Acknowledgements. Tom Dietz was an excellent collaborator on the collecting trip during the spring of 2002 to California, Oregon, Washington, and British Columbia. Cindra Rathbone was very helpful in obtaining samples at the Manchester Dock of the National Marine Fisheries Service laboratory, WA, and in providing facilities for processing sea stars that were collected at Clallam Bay, WA. John Pearce collected Leptasterias spp. from Pigeon Point, CA. We are grateful to the staff at the University of California at Santa Cruz; the Oregon Institute of Marine Biology at Charleston, OR; the NMFS/NWFSC, Manchester, WA, Field Station; Friday Harbor Marine Lab; Bamfield Marine Laboratory; Sheldon Jackson Marine Lab; the NMFS, Kodiak, Fishery Research Center at Kodiak, AK; the NMFS lab at Auke Bay, AK, for providing excellent facilities to conduct sampling studies; and Stanley Rice from the NMFS lab at Auke Bay, AK, for assistance in collection and processing of specimens from Little Port Walter, and Sunshine Cove, AK. Larry Harris from the University of New Hampshire collected Asterias rubens and A. forbesii from the Isles of Shoals and sent them to LSU for processing. Thanks to Cindy Henk of the Socolofsky Microscopy Center at LSU for technical assistance with this paper.

\section{LITERATURE CITED}

Barry JP, Baxter CH, Sagarin RD, Gilman SE (1995) Climaterelated, long-term faunal changes in a California rocky intertidal community. Science 267:672-675

Bouland C, de Puytorac P, Bricourt E (1987) Orchitophrya stellarum, cilié prétendu astome, est un scuticocilié. Ann Sci Nat Zool Biol Anim (Ser 13) 8:249-257

Byrne M, Cerra A, Nishigaki T, Hoshi M (1997) Infestation of the testes of the Japanese sea star Asterias amurensis by the ciliate Orchitophrya stellarum: a caution against the use of this ciliate for biological control. Dis Aquat Org 28:235-239

Byrne M, Cerra A, Nishigaki T, Hoshi M (1998) Male infertility in Asterias amurensis: a new phenomenon resulting from the introduction of the parasitic ciliate Orchitophrya stellarum into Japan. In: Mooi R, Telford M (eds) Echinoderms: San Francisco. Balkema, Lisse, p 203-207

de Puytorac P (1994) Sous-classe des Scuticociliata Small 1967. In: Grassé PP (ed) Traité de zoologie. Tome II (Infusoires Ciliés), fasc. 2 (Systématique). Masson, Paris, p 621-651

Dragesco A, Dragesco J, Coste F, Gasc C, Romestand B, Raymond JC, Bouix B (1995) Philasterides dicentrarchi, n. sp., a histophagous opportunistic parasite of Dicentrarchus labrax (Linnaeus 1758), a reared marine fish. Eur J Protistol 31:327-340

Finlay BJ (2002) Global dispersal of free-living microbial eukaryotic species. Science 296:1061-1063

Flowers JM, Foltz DW (2001) Reconciling molecular systematics and traditional taxonomy in a species-rich clade of sea stars (Leptasterias subgenus Hexasterias). Mar Biol 139:475-483

Goggin CL, Murphy NE (2000) Conservation of sequence in the internal transcribed spacers and 5.8S ribosomal RNA among geographically separated isolates of parasitic scuticociliates (Ciliophora, Orchitophryidae). Dis Aquat Org 40:79-83

Helmuth B, Broitman BR, Blanchette CA, Gilman S and others (2006) Mosaic patterns of thermal stress in the rocky intertidal zone: implications for climate change. Ecol Monogr 76:461-479

Leighton BJ, Boom JDG, Bouland C, Hartwick EB, Smith MJ (1991) Castration and mortality in Pisaster ochraceus parasitized by Orchitophrya stellarum (Ciliophora). Dis Aquat Org 10:71-73

SAS Institute (2003) Statistics version 9.1. SAS Institute, Cary, NC

Stickle WB (1970) Some physiological aspects of the reproductive cycle of the intertidal prosobranch Thais lamellosa (Gmelin, 1792). PhD thesis, University of Saskatchewan, Regina

Stickle WB, DeNoux GJ (1976) Effects of in situ tidal salinity fluctuations on osmotic and ionic composition of body fluid in southeastern Alaska rocky intertidal fauna. Mar Biol 37:125-135

Stickle WB, Weidner EH, Kozloff EN (2001a) Parasitism of Leptasterias spp. by the ciliated protozoan Orchitophrya stellarum. Invertebr Biol 120:88-95

Stickle WB, Rathbone EN, Story S (2001b) Parasitism of sea stars from Puget Sound, Washington, by Orchitophrya stellarum. In: Barker M (ed) Echinoderms 2000. Swets \& Zeitinger, Lisse, p 221-226

Stickle WB, Kozloff EN, Henk MC (2007a) The ciliate Orchitophrya stellarum viewed as a facultative ciliate parasite of asteriid sea stars. Cah Biol Mar 48:9-16

Stickle WB, Kozloff EN, Story S (2007b) Physiology of the ciliate Orchitophrya stellarum and its experimental infection of Leptasterias spp. Can J Zool 85:201-206 